\title{
Uji Beda Efektivitas Ekstrak Biji Rambutan Dengan Ektrak Biji Mangga Terhadap Mortalitas Larva Nyamuk Aedes aegypti
}

\author{
Rien Kusuma Hatmoko ${ }^{1}$ dan Diah Karunia Binawati ${ }^{2}$ \\ ${ }^{1}$ Mahasiswa Prodi Biologi FMIPA Universitas PGRI Adi Buana Surabaya \\ ${ }^{2}$ Staf Pengajar Prodi Biologi FMIPA Universitas PGRI Adi Buana Surabaya
}

\begin{abstract}
The use of chemical larvicides to control mosquito larvae in water reservoirs has a negative impact, causing environmental pollution and resistance to target organisms. The alternative to reduce this impact is using vegetable larvacides from Rambutan Seeds (Nephelium Lappaceum L) and Mango Seeds (Mangifera indica L). This study aims to determine the effectiveness of Rambutan Seed Extract (Nephelium Lappaceum L) and Mango Seed Extract (Mangifera indica L) on the mortality of Aedes aegypti larvae after being treated for 24 hours. This type of research is experimental with a pure experimental study design (true experiment). The treatment concentration given for 24 hours was $0,2 \%, 4 \%$, $6 \%, 8 \%$ of each extract with 5 replications. The samples in the study were III instar Aedes aegypti larvae totaling 800 heads. Data analysis was performed by Anova test and probit test. Based on the results of research on rambutan seed extract (Nephelium lappaceum L) LC50 value of $3.190 \%$ was more effective against mortality of Aedes aegypti larvae than Mango seed extract (Mangifera indica L) LC50 value of $4.758 \%$.
\end{abstract}

Keywords: Rambutan Seeds (Nephelium Lappaceum L), Mango Seeds (Mangifera indica L), mortality of Aedes aegypti larvae.

\section{Pendahuluan}

Indonesia merupakan negara beriklim tropis basah dengan curah hujan yang cukup tinggi saat musim penghujan. Musim hujan adalah musim yang sangat disukai oleh nyamuk - nyamuk untuk berkembangbiak. Penyakit yang sering menjadi permasalahan tiap tahun dimusim hujan ialah Demam Berdarah Dengue (DBD). Data dari Dinas Kesehatan Kota Surabaya tercatat jumlah pendrita DBD pada tahun 2014 sebanyak 816 kasus, tahun 2015 sebanyak 640 kasus, tahun 2016 sebanyak 938 kasus, dan per september 2017 sebanyak 302 kasus. Vektor penularan penyakit ini adalah nyamuk. Gigitan nyamuk Aedes aegypti yang terinveksi virus dungue.

Pemerintah setiap tahunnya membuat program baru guna mengurangi penderita Demam Berdarah Dengue setiap tahunnya. Sosialisasi pengendalian jentik nyamuk yang sering dilakukan dimasyarakat kita ialah dengan melakukan gotong royong pembersihan saluran air, menutup bak penampungan air dan dengan larvasida karena hal tersebut merupakan langkah pencegahan yang tepat, murah, dan mudah dilakukan. Namun, penggunaan larvasida sintetis dalam jangka 
panjang akan berdampak buruk bagi lingkungan sekitar, terutama ekosistem serangga lain yang bukan menjadi sasaran utama.

Saat musim hujan biasanya bersamaan dengan musim panen buah. Buah yang diminati oleh masyarakat pada saat musim hujan adalah buah rambutan dan buah mangga. Umumnya masyarakat tidak mengetahui apa kandungan dan manfaat dari limbah biji tersebut. Padahal biji rambutan dan biji mangga berpotensi sebagai larvasida alami yang ramah lingkungan. Ekstrak biji rambutan dan ekstrak biji mangga mempunyai senyawa bioaktif seperti polivenol, flavonoit, tanin, saponin, dan alkoloid. Senyawa metabolit sekunder yang terkandung dalam biji rambutan dan biji mangga yaitu senyawa flavonoid yang bekerja sebagairacun pernafasan pada larva. Flavonoid, alkaloid, tanin and saponin pada tumbuhan berperan sebagai insektisida dan bersifat toksik terhadap hewan lain (Pedro M. Gutierrez, dkk. 2014).

\section{Metode Penelitian}

Rancangan penelitian yang akan digunakan adalah Rancangan Acak Lengkap (RAL) dengan hewan uji, umur, bobot dan faktor lainnya sama. Penelitian ini menujukkan beda efektifitas ekstrak biji rambutan (Nephelium lappaceum L), dan ekstrak biji mangga (Mangifera indica L) terhadap larva nyamuk Aedes aegypti intar III. Perlakuan konsentrasi ekstrak yang diberikan yakni, 0, $\% 2 \%, 4 \%, 6 \%, 8 \%$ dengan 5 kali ulangan selama 24 jam.

Populasi yang digunakan pada penelitian ini yaitu larva nyamuk Aedes aegypti instar III. Populasi diperoleh saat penelitian yang dilakukan di Laboratorium Tropical Disease Center (TDC) Universitas Airlangga Jl. Mulyorejo - Surabaya.

Sampel pada penelitian ini adalah nyamuk Aedes aegypti instar III kondisi baik (bergerak aktif) berusia 2-3 hari yang memiliki panjang tubuh $4-5 \mathrm{~mm}$ sebanyak 20 ekor tiap perlakuan dan dilakukan pengulangan sebanyak 5 kali.

\section{Pembuatan Ekstrak}

Pembuatan ekstrak dimulai dengan menyiapkan masing masing biji kemudian dicuci bersih kemudian diiris tipis untuk memudahkan proses pengeringan diangin - anginkan setelah dirasa biji kering, setelah dirasa kering masing - masing biji di blender/dihaluskan sampai menjadi serbuk ayak untuk memisahkan bagian yang halus dan kasar. Serbuk simplisia yang sudah jadi sebanyak 100gr direndam dengan etanol $96 \%$ sebanyak $1000 \mathrm{ml}$ rendam selama 3 hari. Setelah 3 hari, saring dengan kertas saring kemudian maserat sampai menghasilkan maserat bening. Maserat didestilasi dengan suhu $70^{\circ} \mathrm{C}$ hingga pekat dan diperoleh ekstrak ethanol kental. 


\section{Pemberian Esktrak}

Membuat larutan Ekstrak biji rambutan (Nephelium lappaceum $L$ ) dan ekstrak biji mangga (Mangifera indica L) dengan aquades dengan konsentrasi $2 \%, 4 \%, 6 \%, 8 \%$ sebanyak 5 kali ulangan pada gelas, selanjutnya memasukkan larva nyamuk Aedes aegypti instar III sebanyak 20 ekor setiap perlakuan, tunggu selama 24 jam.

\section{Teknik Pengumpulan dan Analisis Data}

Megamati dan menghitung larva nyamuk Aedes aegypti instar III yang mati setelah diberi perlakuan selama 24 jam larvasida ekstrak biji rambutan (Nephelium lappaceum L) dan ekstrak biji mangga (Mangifera indica L.). analisis data mortalitas larva nyamuk Aedes aegypti dengan Uji Anova dan Uji Probit.

\section{Hasil Dan Pembahasan}

\section{Rata-rata mortalitas larva Aedes aegypti yang diberi perlakuan ekstrak biji rambutan selama 24 jam}

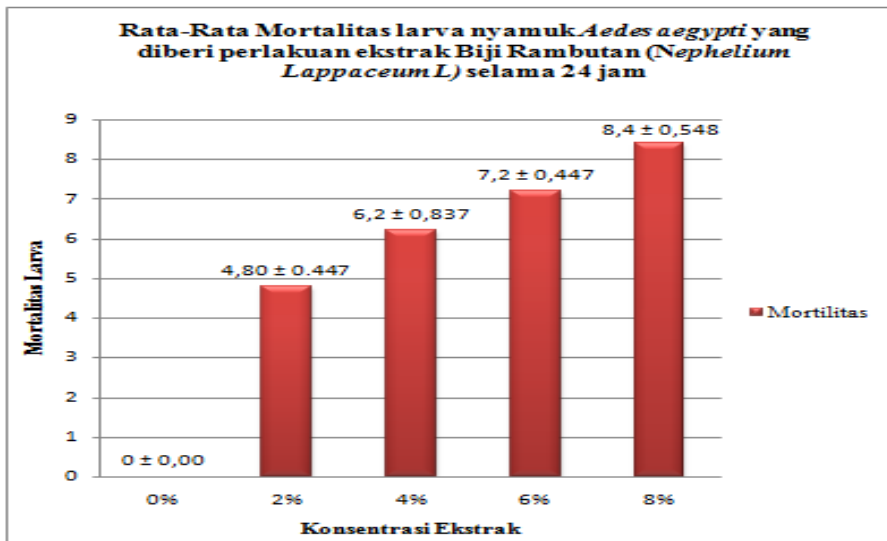

Gambar 1 mortalitas larva Aedes aegypti yang diberi perlakuan ekstrak biji rambutan selama 24 jam

Diagram

menunjukkan bahwa rata - rata mortalitas kematian larva Aedes aegypti setelah diberi perlakuan ekstrak biji rambutan (Nephelium lappaceum l) selama 24 jam pada konsentrasi $0 \%$ sebanyak $0 \pm 0,00$ larva, konsentrasi $2 \%$ sebanyak 4,80 \pm 0.447 larva, konsentrasi $4 \%$ sebanyak $6,2 \pm 0,837$ larva, konsentrasi $6 \%$ sebanyak $7,2 \pm$ 0,447 larva, dan konsentrasi $8 \%$ sebanyak 8,4 $\pm 0,548$ larva.

Bahan - bahan aktif yang terkandung dalam Ekstrak Biji Rambutan (Naephelium lappaceum $L)$ yang bersifat racun pada larva Aedes aegypti diantaranya adalah ; 
Polifenol menyebabkan denaturasi protein (proteolisis) penyusun dinding sel, sehingga sel akan mengalami gangguan metabolisme dan fisiologis dan menyebabkan proses kerusakan sel (Wibawa, 2012), Flavonoid masuk ke dalam tubuh larva melalui siphon yang berada di permukaan air dan menimbulkan kelayuan pada saraf, serta kerusakan pada siphon sehingga larva tidak bisa bernapas dan akhirnya mati (Dinata dalam Zuldarisma, 2013), Tanin menghalangi serangga dalam mencerna makanan dan juga menyebabkan gangguan penyerapan air pada organisme, sehingga dapat mematikan organism, saponin dapat menurunkan tegangan permukaan selaput mukosa saluran pencernaan larva sehingga dinding saluran pencernaan menjadi korosif dan akhirnya rusak (Aminah, 2001).

\section{Rata-rata mortalitas larva Aedes aegypti yang diberi perlakuan ekstrak biji mangga selama 24 jam}

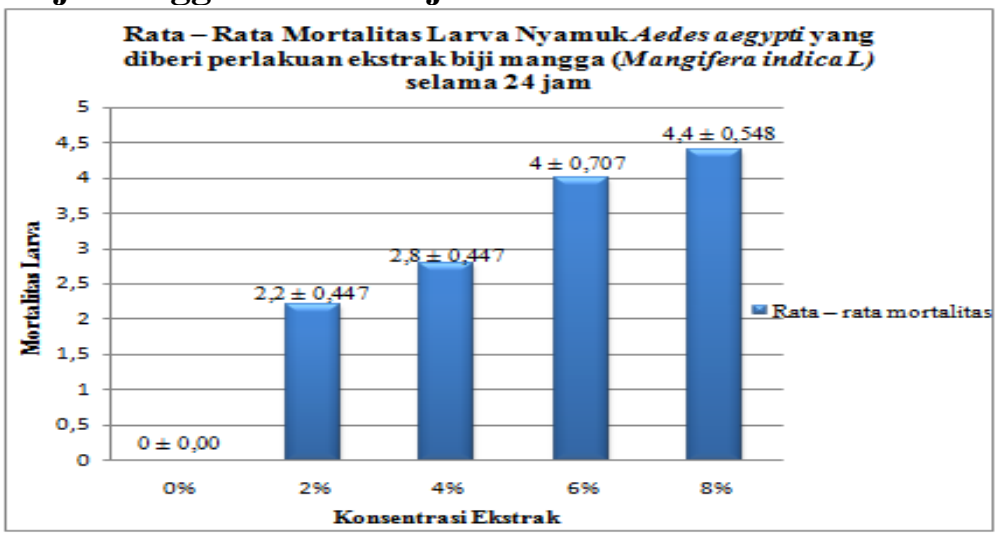

Gambar 2 Mortalitas larva Aedes aegypti yang diberi perlakuan ekstrak biji mangga selama 24 jam

Diagram

menunjukkan bahwa rata-rata mortalitas kematian larva Aedes aegypti setelah diberi perlakuan ekstrak biji mangga (Mangifera indica L) selama 24 jam pada konsentrasi $0 \%$ sebanyak $0 \pm 0,00$ larva, konsentrasi $2 \%$ sebanyak 2,2 \pm 0.447 larva, konsentrasi 4\% sebanyak $2,8 \pm 0,0,447$ larva, konsentrasi $6 \%$ sebanyak $4 \pm 0,707$, dan konsentrasi $8 \%$ sebanyak $4,4 \pm$ 0,548 larva.
Bahan-bahan aktif yang terkandung dalam Ekstrak Biji Mangga (Mangifera indica L) yang bersifat racun pada larva Aedes aegypti diantaranya adalah ; Polifenol menyebabkan denaturasi protein (proteolisis) penyusun dinding sel, sehingga sel akan mengalami gangguan metabolisme dan fisiologis dan menyebabkan proses kerusakan sel (Wibawa, 2012), Flavonoid masuk ke dalam tubuh larva melalui siphon yang 
berada di permukaan air dan menimbulkan kelayuan pada saraf, serta kerusakan pada siphon sehingga larva tidak bisa bernapas dan akhirnya mati (Dinata dalam Zuldarisma, 2013), Tanin menghalangi serangga dalam mencerna makanan dan juga menyebabkan gangguan penyerapan air pada organisme, sehingga dapat mematikan organism, saponin dapat menurunkan tegangan permukaan selaput mukosa saluran pencernaan larva sehingga dinding saluran pencernaan menjadi korosif dan akhirnya rusak (dalam Aminah, 2001), Alkaloid yang masuk ke dalam tubuh larva melalui absorbsi dan mendegradasi membran sel kulit. Selain itu alkaloid juga dapat mengganggu sistem kerja saraf larva (Dinata dalam Zuldarisma,2013).

Hasil penelitian tersebut diatas, jika dibandingkan dengan penelitian sebelumnya yang

\section{Beda efektivitas Ekstrak Biji Rambutan (Naephelium lappaceum L) dengan Ekstrak Biji Mangga (Mangifera indica L)}

Pada penelitian ini meski kedua ekstrak memiliki kandungan senyawa metabolit sekunder yang dilakukan oleh Siti Asiah, dkk (2009) mengenai efektivitas ekstrak etanol daun rambutan (Nephelium lappaceum L.) terhadap kematian larva nyamuk Aedes aegypti instar III, pada konsentrasi terendah $0,025 \%$ rata-rata kematian larva sebesar $1 \%$, konsentrasi $0,05 \%$ ratarata kematian larva sebesar $4 \%$, konsentrasi $0,1 \%$ rata-rata kematian larva sebesar $31 \%$, konsentrasi $0,2 \%$ rata-rata kematian larva sebesar $87 \%$, konsentrasi $0,4 \%$ rata-rata kematian larva sebesar $92 \%$, dan konsentrasi $0,8 \%$ rata-rata kematian larva sebesar $99 \%$.

Hasil penelitian tersebut sesuai dengan pernyataan Adam (2005) yang menyatakan bahwa semakin tinggi konsentrasi larvasida yang diberikan maka semakin tinggi pula rerata kematian larva Aedes aegypti.

hampir sama namun efektiitas keduanya sangat berbeda yakni; perlakuan Ekstrak Biji Rambutan (Nephelium Lappaceum L) nilai $\mathrm{LC}_{50}$ sebesar 3,190\% dan perlakuan Ekstrak Biji Mangga (Mangifera indica $L)$ nilai $\mathrm{LC}_{50}$ sebesar $4,758 \%$.

\begin{tabular}{|c|c|c|}
\hline \multirow{2}{*}{ Probability } & $\begin{array}{c}\text { Ekstrak Biji Rambutan } \\
\text { (Nephelium Lappaceum L) }\end{array}$ & $\begin{array}{c}\text { Ekstrak Biji Mangga } \\
\text { (Mangifera indica L) }\end{array}$ \\
\cline { 2 - 3 } & Estimate & Estimate \\
\hline 0,5 & 3,190 & 4,758 \\
\hline
\end{tabular}

$\begin{array}{rrlr}\text { Perbedaan efektivitas kedua } & \text { konsentrasi dipengaruhi oleh } \\ \text { ekstrak pada masing-masing } & \text { beberapa faktor, diantaranya adalah }\end{array}$ 
usia dan bagian tanaman yang digunakan, senyawa metabolit sekunder yang terkandung yang bersifat racun pada larva nyamuk Aedes aegypti instar III, kelarutan senyawa ekstrak dalam proses pembuatan larutan perlakuan, kepekatan larutan ekstrak, pelarut yang digunakan pada saat pelarutan ekstrak.

\section{Kesimpulan dan Saran}

\section{Kesimpulan}

1. Adanya perbedaan efektivitas Ekstrak Biji Rambutan (Nephelium lappaceum, L.) dengan Ekstrak Biji Mangga (Mangifera indica L) terhadap mortalitas larva Aedes aegypti.

2. Ekstrak Biji Rambutan (Nephelium lappaceum, L.) lebih efektiv terhadap mortalitas larva Aedes aegypti daripada Ekstrak Biji Mangga (Mangifera indica L) dengan nilai $\mathrm{LC}_{50}$ sebesar $3,190 \%$.

\section{Saran}

1. Disarankan untuk penelitian lebih lanjut mengenai Ekstrak Biji Rambutan

(Naephelium

lappaceum L) dan Ekstrak Biji Mangga (Mangifera indica L) mengenai kadar senyawa metabolit sekunder pada masing - masing ekstrak.

2. Disarankan untuk penelitian lebih lanjut mengenai Ekstrak Biji Rambutan (Naephelium lappaceum L) dan Ekstrak Biji Mangga (Mangifera indica L) sebagai bioinsektisida nabati pada larva nyamuk lain.

3. Disarankan untuk menggunakan abate sebagai kontrol negatif pada penelitian larvasida nabati.

4. Disarankan agar pemerintah membuat program mengenai pembuatan dan penggunaan bioinsektisida nabati dari beberapa tanaman yang mudah ditemukan di lingkungan sekitar.

\section{Daftar Pustaka}

Adam. 2005. Uji Toksisitas Ekstrak Biji Srikaya (Annona squamosa Linn) Terhadap Larva Aedes aegypti. Tesis. Program Pascasarjana UGM. Universitas Gajah Mada: Yogyakarta.

Cronquist A. 1981. An Integrated System of Classification of Flowering Plants.Columbia University Press. New York.diakses dari http://www.sciepub.com/ref erence/147073 pada tanggal 6 jaunari 2018.

Dalimartha, S. 2009. Atlas Tumbuhan Obat Indonesia Jilid 1. Jakarta : Trubus Agriwidya.

Dalimartha, Setiawan. 2003. Atlas

Tumbuhan Obat

Indonesia. Jilid 3. Puspa Swara Jakarta.

Heyne, K. 1987. Tumbuhan Berguna Indonesia Jilid II. Badan Litbang Kehutanan. Jakarta. $631 \mathrm{hlm}$.

Irianto, K., 2014, Epidemiologi Penyakit Menular dan Tidak 
Mmenular Panduan Klinis, Bandung: ALFABETA.

Ishartadiati, K., 2012, Aedes aegypti Sebagai Vektor Demam Berdarah

Dengue.Departemen Kimia FMIPA Universitas

Sumatera Utara.

Kementrian Kesehatan Republik Indonesia, 2014, Profil Kesehatan Indonesia 2013, Jakarta: Kemenkes RI.

Kementrian Kesehatan Republik Indonesia, 2015, Data dan Informasi Tahun 2014 (Profil Kesehatan Indonesia), Jakarta: Kemenkes RI.

Komisi Pestisida, 2012, Metode Standar Pengujian Efikasi Pestisida Rumah Tangga dan Pengendalian Vektor, Direktorat Pupuk dan Pestisida, Direktorat Jenderal Prasarana dan Sarana Pertanian: Kementerian Pertanian.

Mahendra, B., 2005, 13 Jenis Tanaman Obat Ampuh, Jakarta: Penebar Swadaya. Melissa C., et al. (2010). Impact Of Water Intake on Energy Intake and WeightStatus : a Systemic Review. Nutrition Reviews. 68 : 505-21. Fromhttp://dx.doi.org/10.11 $\underline{11 / j .1753-4887.2010 .00311 .}$ $\underline{\mathrm{X}}$

Notoatmodjo, Soekidjo, 2010, Metodologi Penelitian Kesehatan, Jakarta: Rineka Cipta.
Novizan, 2004, Membuat dan Memanfaatkan Pestisida Ramah Lingkungan,Jakarta: Agromedia.

Pangestika, Gesty Megalaksari Widya, 2014, Status Resistensi Vektor Demam Berdarah Dengue (Aedes aegypti) terhadap Temephos Berdasarkan Endemisitas di Kecamatan Mijen Kota Semarang, Skripsi, Semarang: Universitas Diponegoro.Prihatman Kemal, 2000, Budidaya Padi, Pendayagunaan Dan Pemasyarakatan Ilmu Pengetahuan Dan Teknologi, Jakarta

Priyatno, Dwi, 2008, SPSS Untuk Analisis Data \& Uji Statistik, $\quad$ Yogyakarta: Mediakom.Rahmat Rukmana. 1997. Usaha Tani Jagung. Penerbit Kanisius. Jogjakarta.

Ribeiro, S. M. R., J. H. Queiroz, M. E. L. R. Queiroz, F. M. Campos and H. M. P. Sant'ana. 2007. Antioxidant in mango(Mangifera indica L.) Pulp. Plant Foods for Human Nutrition, V. 62 (1), 13-17.

Sutanto, I., Ismid, I.S., Sjarifuddin, P.K., Sahela, S., 2009, Parasitologi Kedokteran Edisi Keempat, Jakarta: Fakultas Kedokteran Universitas Indonesia.

Soegijanto, S., 2008. Demam Berdarah Dengue, Edisi 
Kedua, Surabaya: Airlangga University Press.

World Health Organization2012, Global Strategy for Dengue Prevention and Control, Geneva: WHO Press.

Zulhipri, Kartika. I. R., dan Sumaji.

I, 2007, Uji Fitokimia dan
AktivitasAntidiabetes

Ekstrak Biji rambutan

(Nephelium lappaceum L) denganBerbagai

Pelarut, Ebers Papyrus, 13

(3), 89-97. 